\title{
Charakterystyka znaczeń wyrażeń tak naprawdę, na pewno i oczywiście
}

\section{Characterizing the meanings of the Polish "tak naprawdę", "na pewno" and "oczywiście"}

\author{
Bożena Niećko-Bukowska \\ INSTYTUT JĘZYKOZNAWSTWA, UNIWERSYTET IM. ADAMA MICKIEWICZA \\ AL. NIEPODLEGLOŚCI 4, 61-874 POZNAŃ \\ bniecko@amu.edu.pl
}

\begin{abstract}
The following article characterizes the meanings of the Polish expressions 'tak naprawdę' ('prawda', eng. 'truth'; truthfully, truly, really), 'na pewno' ('pewność', eng.'certainty'; 'surely', 'certainly') and 'oczywiście' ('oczywisty', eng. 'obvious'; 'of course', 'obviously'). The findings of the study are based on a questionnaire which generated reactions via free association test completed by students of the filologia course at Adam Mickiewicz University's Faculty of Modern Languages and Literatures. The aim of the article is to isolate the possible dimensions of meaning for the expressions in question, to investigate the functions they fulfil in colloquial usage as well as to present the functioning and understanding of what is 'true', 'certain' and 'obvious'.
\end{abstract}

Omawiane w niniejszym artykule charakterystyki znaczeń wyrażeń „tak naprawdę”, „na pewno” i „oczywiście” opracowane zostały na podstawie badań ankietowych $\mathrm{z}$ wykorzystaniem metody skojarzeniowej, przeprowadzonych wśród studentów kierunku filologia na Wydziale Neofilologii UAM. Celem pracy jest zaprezentowanie możliwych do wyodrębnienia wymiarów semantycznych dla badanych wyrażeń, prześledzenie funkcji jakie pełnią $\mathrm{w}$ potocznym użyciu i przedstawienie sposobów funkcjonowania i rozumienia tego, co „prawdziwe”, „pewne” czy „oczywiste”.

\section{Analiza liczbowa}

Generalnie, wyróżnia się dwa typy znaczenia: pojęciowe (związane $\mathrm{z}$ definicjami słów) oraz skojarzeniowe. Znaczenia wyrażeń typu skojarzeniowego związane są $\mathrm{z}$ indywidualnym rozumieniem przez mówiącego. Do 100 studentek i studentów studiów pierwszego stopnia w roku akademickim 2013/14 skierowano następującą instrukcję: Proszę 
wypisać możliwe znaczenia wyrażenia „X”. W miejsce „X” wstawiono: „tak naprawdę”, „na pewno” lub „oczywiście”. Respondenci podzieleni zostali na dwie grupy: pierwsza w liczbie 50 osób udzielała odpowiedzi dla „tak naprawdę" i „na pewno”, druga dla wyrażenia „oczywiście”. W sumie otrzymano 408 reakcji. W tabeli 1 przedstawiono charakterystyki dotyczące: sumy wszystkich uzyskanych reakcji dla danego wyrażenia (SWR), średnią liczbę reakcji oraz siłę reakcji dominującej (liczba osób z grupy, od której uzyskano reakcję najczęstszą).

Tabela 1: Dane dotyczące produktywność haset

\begin{tabular}{|l|c|c|c|}
\hline Wskaźnik liczbowy & $\begin{array}{c}\text { TAK } \\
\text { NAPRAWD } \\
\text { E }\end{array}$ & $\begin{array}{c}\text { NA } \\
\text { PEWNO }\end{array}$ & $\begin{array}{c}\text { OCZYWIŚCI } \\
\text { E }\end{array}$ \\
\hline SWR & 127 & 129 & 152 \\
\hline Średnia & 2,54 & 2,58 & 3,04 \\
\hline Siła reakcji dominującej & 17 & 14 & 9 \\
\hline
\end{tabular}

Najwięcej reakcji generowali respondenci dla wyrażenia „oczywiście”. Reakcja dominująca przy „oczywiście” to jasne, dla „tak naprawdę” to $w$ rzeczywistości, a dla „na pewno”: na sto procent, z pewnością.

W świetle Dociekań filozoficznych L. Wittgensteina znaczenie to sposób użycia. W paragrafie 11 Filozof przyrównał słowa do narzędzi, posługując się metaforą skrzynki z narzędziami1. Rozważania nad istotą znaczenia wpisują się $\mathrm{w}$ bogate tradycje filozofii lingwistycznej głoszące, przykładowo, że wyrażenie ma znaczenie w nurcie życia, że znaczenie związane jest z kontekstem, z konkretnymi wypowiedziami, aktami mowy. Zebrane dane podzielono na dwie grupy, zbiory odpowiedzi: (1) podające wyrażenia synonimiczne, (2) ukazujące znaczenie poprzez opisanie sposobu używania wyrażenia „X”. Proporcje tych dwóch grup odpowiedzi w SWR przedstawiono w tabeli nr 2.

Tabela 2: Stosunek procentowy odpowiedzi w zbiorze „sposoby użycia” $i$,synonimy” do $S W R$

\begin{tabular}{|c|c|c|}
\hline WYRAŻENIA & $\begin{array}{c}\text { SPOSOBY } \\
\text { UŻYCIA }\end{array}$ & SYNONIMY \\
\hline $\begin{array}{c}\text { TAK } \\
\text { NAPRAWDE }\end{array}$ & $44 \%$ & $56,00 \%$ \\
\hline NA PEWNO & $45,7 \%$ & $54,3 \%$ \\
\hline OCZYWIŚCIE & $32,90 \%$ & $67,10 \%$ \\
\hline
\end{tabular}

Inaczej w Traktacie logiczno-filozoficznym, gdzie Wittgenstein uważał, że wyrażenie ma znaczenie (tylko) w zdaniu (Teza 3.314). 


\section{Prezentacja wymiarów dla wyrażeń „tak naprawdę", „na pewno" i „oczywiście”}

\section{2a. Charakterystyka według zbioru SYNONIMY}

$\mathrm{Z}$ uwagi na ilość i jakość zebranych danych, wyodrębniono w obu zbiorach wymiary, które niekiedy zostały podzielone na mniejsze - podwymiary. Każdy z (pod)wymiarów został nazwany w taki sposób, aby jak najlepiej oddać znaczenia, które zostały do niego przyporządkowane ${ }^{2}$. (Wszystkie reakcje otrzymane od respondentów zaznaczone zostały kursywą). Reakcje wspólne dla wyrażeń „tak naprawdę” i „na pewno” oznaczono przez podkreślenie, dla wyrażeń „na pewno” i „oczywiście” przez pogrubienie, a dla „tak naprawdę” i „oczywiście” przez podkreślenie i pogrubienie. (W nawiasach podano ich udziały procentowe w zbiorze).

Odpowiedzi w ramach SYNONIMY dla „tak naprawdę” przyporządkowano do następujących wymiarów:

PRAWDA (36,6\%): prawdę mówiąc; szczerze mówiac; prawda jest; prawdziwie; zgodnie z prawda; nie kłamiąc; na serio;

RZECZYWISTOŚĆ (25,4\%): w rzeczywistości, rzeczywiście;

WŁAŚCIWOŚĆ (11,3\%): właściwie;

UOGÓLNIENIE (5,6\%): ogólnie rzecz biorac; $w$ sumie to; tak generalnie; wprawdzie jest tak, że;

FAKTY(5,6\%): faktycznie; wedtug stanu faktycznego;

ISTOTA (SPRAWY) (5,6\%): $w$ rzeczy samej; $\boldsymbol{w}$ istocie; $w$ zasadzie;

INNE (9,9\%): na pewno; poważnie; na dobra sprawę; jednak.

\section{Dla „na pewno”:}

PEWNOŚĆ (61,4\%): na sto procent; $z$ pewnościa; pewnie; pewność; jestem pewien; niewątpliwie; bez watpienia; bankowo; jak $w$ banku;

STANOWCZOŚĆ (15,7\%): nieodwolalnie; jestem utwierdzona $w$ tym, że; musi tak być; nie może być inaczej; musieć; zdecydowanie; niezawodnie; niechybnie; tak, a nie inaczej;

JASNOŚĆ, OCZYWISTOŚĆ (7,2\%): jasne, że tak; jest dokładnie, tak że; jest tak; tak właśnie to wyglada; ależ oczywiście;

PRAWDOPODOBIEŃSTWO (4,3\%): najprawdopodobniej; catkiem prawdopodobne; zapewne;

INNE (11,4\%): naprawdę; faktycznie; rzeczywiście; wierzę, że tak jest.

\section{Dla „oczywiście3”:}

\footnotetext{
${ }^{2}$ Bardzo dziękuję Pani Profesor dr hab. Nawoi Mikołajczak-Matyi z Instytutu Językoznawstwa UAM za konsultacje merytoryczne dotyczące budowy wymiarów.

${ }^{3}$ Zob., Niećko-Bukowska, 2016: Oczywiście i po prostu - charakterystyka znaczeń wyrażeń. (Zainteresowana/y też tam znajdzie zaprezentowane wyniki badań / wymiary w grupie „synonimy” i „sposób użycia” / dla wyrażenia „oczywiście”, ale w zestawieniu z materiałem badawczym dla wyrażenia ,po prostu”).
} 
PEWNOŚĆ (32,3\%): absolutnie4; bez dwóch zdań; bez żadnych wątpliwości; bez watpienia; bezwarunkowo; najzupetniej; na sto procent; nie ulega to watpliwości; jak najbardziej; coś jest pewne; $\underline{\text { na }}$ pewno; pewne; pewnie; pewnie, że tak; pewnie, że nie; prawda; $\mathbf{z}$ pewnościa; naprawdę;

JASNOŚĆ (17,6\%): jasna sprawa; jasne; jasno; jasny; to jasne; rzecz jasna; klarownie; $w$ sposób jasny; wyraźnie;

PRZYTAKIWANIA (16,7\%): owszem; tak 5; racja; raczej tak; właśnie;

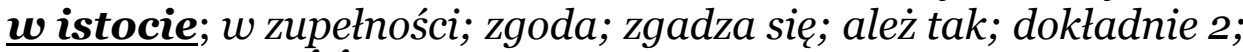

NATURALNOŚĆ (6,9\%): naturalnie;

PRZEWIDYWALNOŚĆ (6,9\%): łatwe do przewidzenia; można się było tego spodziewać; nie ma innej możliwości; tak, jak podejrzewatam/em; jak zwykle; coś co jest ogólnie znane;

ZROZUMIAŁOŚĆ (5,9\%): rozumie się samo przez się; jak wiadomo; nie wymaga szerszych wyjaśnien; coś jest wiadome; (odnosi się do czegoś) co powszechnie uznawane za prawdę, regutę;

OCZYWISTOŚ́ (5,9\%): coś oczywistego; oczywiste; oczywistym jest, $\dot{z} e \ldots$;

BEZPROBLEMOWOŚĆ (2,9\%): nie ma problemu; nie ma sprawy; bez problemu;

INNE (4,9\%): pod warunkiem; szczerze mówiac; synonim wyrażenia naprawdę; synonim po prostu; po prostu.

Wspólne odpowiedzi dla „tak naprawdę” i „na pewno”: faktycznie i rzeczywiście stanowią typowe dla tych wyrażeń reakcje synonimiczne. Zarówno „pewność” jak i „prawda” odsyłają do sfery faktów. Co ciekawe, za synonim „tak naprawdę” wymieniono na pewno, zaś za synonim „na pewno" - naprawdę. To, co uważane jest za „prawdziwe” uchodzi zarazem za „pewne”, ale zachodzi także odwrotna relacja. Trzeba jednak rozróżnić dwa przypadki „pewności”: „pewność co do czegoś” i „pewność o prawdziwości tego czegoś”. Na gruncie subiektywizmu można przyjąć, że „pewność co do czegoś” jest zarazem „pewnością o prawdziwości tego czegoś”. Ale obok „pewności o prawdziwości czegoś” - warto pamiętać, że istnieje także „prawda o tym czymś”.

Dla pary „tak naprawdę”/,oczywiście” odnaleźć można wspólne reakcje jak: szczerze mówiąc, $w$ istocie, na pewno. Nie wszystko co „prawdziwe”, chociaż (może i) uchodzi za „pewne” jest „oczywiste”. „Oczywistość” jest „jasna”, „wyraźna”, czasem „prosta”, ale nie „prawda”, ponieważ ta ostatnia najczęściej bywa skryta albo gorzka. Trzecia para: „na pewno”/ oczywiście” mają wspólne nie tylko niektóre reakcje, ale i podwymiary: PEWNOŚĆ (na sto procent; $z$ pewnościa; pewnie; bez watpienia), JASNOŚ́́, OCZYWISTOŚĆ. Kiedy „prawda” jest oczywista, a więc nieskryta, mimo że może być gorzka, będzie „szczera”. Pewności towarzyszy oczywistość, a prawdziwości pewność.

\footnotetext{
${ }^{4}$ Więcej na temat ,absolutnie” zobacz: Wawrzyniak, 2016: 66-67.
} 


\section{2b. Charakterystyka wyrażeń według „SPOSOBÓW UŹYCIA”}

W przypadku drugiej, wyodrębnionej grupy („sposób użycia”) zebrane dane zostały pogrupowane w następujący sposób:

Dla wyrażenia „tak naprawdę”:

Odpowiedzi wskazujące na PRAWDZIWOŚĆ WYPOWIEDZI $(53,6 \%)$

SPROSTOWANIE, PRZYZNANIE SIE DO POWIEDZENIA NIEPRAWDY: kiedy chcemy powiedzieć prawdę po wcześniejszym kłamstwie5; kiedy żartujemy lub naginamy rzeczywistość a następnie prostujemy to co powiedzieliśmy; próba sprostowania czegoś; wskazanie, że wcześniej się kłamało; pokazanie czegoś co wcześniej się ukrywało; gdy chcemy się "zdemaskować"; zastosowanie kłamstwa i szybkie wyjaśnienie sytuacji; chęć przyznania się do czegoś 2; przyznanie się do czegoś, po skłamaniu; przyznanie się do czegoś; ostateczna, nieco wymuszona wola wyjawienia „prawdy”; wyjawienie prawdy;

KORYGOWANIE, WYPROWADZANIE Z BEĘDU: wyjaśnienie sytuacji bez zastosowania kłamstwa; wyprowadzenie $z$ błędu; rozróżnienie informacji błędnych od prawdziwych; koryguje błędna lub fałszywa odpowiedź; używane w celu odróżnienia rzeczywistości od tego, co może tylko wydawać się prawda; uświadomienie rozmówcy, który jest $w$ błędzie; $w$ przeciwieństwie do tego co myślisz; doszukiwanie się głębszego sensu wypowiedzi od powszechnie przyjętego za prawdziwy; lecz; ale;

POTWIERDZENIE PRAWDZIWOŚCI: podkreślenie prawdziwości informacji; jeśli coś jest prawdziwe; oznacza, ̇̇e uważamy coś za prawdziwe; potwierdzenie, że coś wcześniej powiedzianego jest istotne $i$ zgodne $z$ prawda; potwierdzenie informacji; dodatkowe potwierdzenie, że mówię prawdę; potwierdzenie $w$ razie wątpliwości.

Odpowiedzi ukierunkowane na INFORMACJE O /BUDOWIE I

TREŚCI/WYPOWIEDZI (46,4\%):

POKAZANIE KONTRASTU: podkreślenie kontrastu między informacja fatszywa a jej późniejsza weryfikacją; pokazanie kontrastu między tym co się czuje a tym co się robi; wyrażenie kontrastu między teoria a praktyka; przedstawienie opozycji jakiegoś stwierdzenia; kiedy chcemy wskazać sprzeczność, nieprawidłowość;

PODSUMOWANIE, UŚCIŚLENIE, ZAKOŃCZENIE TEMATU ROZMOWY: jako podsumowanie informacji; podsumowanie tematu rozmowy; uściślenie; doprecyzowanie jakiegoś stwierdzenia; odcięcie się od kontynuacji tematu rozmowy;

STOSUNEK DO WYPOWIEDZI, WZMOCNIENIE WYPOWIEDZI: podniesienie wartości riposty; używane celem dodania emfazy do danego zdania; wzmocnienie wypowiedzi, gdy ktoś nie chce nam uwierzyć; stuży podkreśleniu wyrażanej opinii; jestem bardzo do tego przekonany;

\footnotetext{
${ }^{5}$ Poszczególne reakcje (odpowiedzi respondentów) zostały oddzielone od siebie „średnikiem”.
} 
„uważaj bo ważna informację przekazuję; używamy by wskazać realny stan naszej wiedzy;

PODKREŚLENIE/WSKAZANIE ISTOTY: podkreślenie istoty problemu; podkreślenie tego co jest najważniejsze; wskazanie, że sprawa o której mowa została przemyślana; kiedy przechodzi do meritum sprawy, o co chciałby zapytać, powiedzieć;

\section{POZOSTAŁE: PRZEDSTAWIANIE OPINII, WYRAŻANIE} EMOCJI, PODTRZYMANIE PEYNNOŚCI WYPOWIEDZI: przedstawienie subiektywnej opinii na jakiś temat; wstęp do wygtoszenia nieoficjalnego, półoficjalnego stanowiska; używane by podtrzymać płynność wypowiedzi, tym samym trudno podać jego znaczenie; „puste wyrażenie", stuży wyrażaniu emocji; oznacza szczera chęć lub niechęć do czegoś.

\section{Dla wyrażenia „na pewno”:}

Trzy STOPNIE PEWNOŚCI:

WYSOKI (71,4\%):

WYRAŻENIE PEWNOŚCI: wyrażenie pewności 3; podkreśla, że jest się czegoś pewnym; oddaje pewność; możesz być pewien; gdy jest pewien, że coś właśnie jest prawdziwe; pokazanie pewności w tym co się mówi; jeśli jesteśmy czegoś pewni; pewność, że coś istnieje; przedstawienie swojej calkowitej pewności wobec jakiejś sytuacji; gdy jesteśmy na 10o\% pewni jakiejś sytuacji; podkreślenie, że jest się pewnym podawanych informacji; jest się pewnym czegoś; ukazuje, że coś jest pewne; zapewnienie 5;

WYRAŻENIE PRZEKONANIA: jestem przekonany, że; oddaje przekonanie osoby mówiącej co do tematu; z przekonaniem, że tak się stanie, tak jest; gdy jesteśmy o czymś przekonani; kiedy subiektywnie uważamy coś za prawdę; coś z pewnościa się wydarzy(ło); subiektywne przekonanie o prawdziwości jakiegoś stwierdzenia; coś miało miejsce; jeśli się czegoś domyślamy, mamy przesłanki;

POTWIERDZENIE: potwierdzam coś $w$ co wierzę; potwierdzam coś, do czego jestem przekonana (mówione $z$ ironia oznacza swoje przeciwieństwo); potwierdzenie pewności; stanowcze potwierdzenie; kiedy chcę coś potwierdzić;

UWIARYGODNIENIE: postugujemy się by nadać wypowiedziom wysoki stopień pewności, wiarygodności; wzmocnienie wypowiadanych stów, uwierzytelnienie ich; wzmocnienie przekazywanych treści; celowe podkreślenie prawdziwości stwierdzenia; zapewnienie, że coś jest prawda; używane $w$ celu podbudowania czyjejś pewności.

ŚREDNI (9\%):

PRZYPUSZCZENIE: wyrażenie przypuszczenia odnoszącego się do przyszłości; wyrażenie swojej opinii, przypuszczeń; kiedy coś przewidujemy; coś będzie zrobione; wyrażenie przypuszczenia.

NISKI (19,6\%):

ZASYGNALIZOWANIE WĄTPLIWOŚCI, POWĄTPIEWANIE: $w$ zależności od intonacji może wyrażać wątpliwość $i$ niewiarę $w$ to, co 
Bożena Niećko-Bukowska: Charakterystyka znaczeń wyrażeń tak naprawdę, na pewno i oczywiście

mówi rozmówca; $w$ pytaniach by zasygnalizować rozmówcy, że niekoniecznie ma rację; postugujemy się gdy styszymy coś, co wydaje nam się nieprawdopodobne; ironicznie w sytuacjach niedowierzania; na początku zdania pytającego $w$ razie watpliwości; wyraża ironię; używane ironicznie by podkreślić absurdalność; gdy czegoś byśmy nigdy nie zrobili;

UPEWNIENIE, ZAPEWNIENIE: kiedy chcemy się upewnić, pytamy; potrzeba upewnienia się, że informacje sa poprawne; upewnienie;

INNE: EMOCJE, DZIAŁANIE NA INNYCH: wyraża irytację; obietnica; podnieść na duchu.

Dla wyrażenia „oczywiście”:

WYRAZ ZGODY / (DEZ)APROBATY (32\%): wyrażenie aprobaty; pokazanie aprobaty; wyrażamy absolutna pewność czegoś; wyrażenie zgody; zgadzając się z kimś; wyraża, że zgadzamy się z czymś/kimś; zgadzam sie 5; pozytywna reakcja na pytanie; pochwata; wyraz gotowości do zrobienia czegoś; sarkastycznie: nie; dezaprobata;

POTWIERDZENIA (24\%): potwierdzam 3; potwierdzenie 4; potwierdzenie stuszności stwierdzenia; chcemy coś zdecydowanie potwierdzić; można potwierdzić tym słowem każda kwestię; $w$ znaczeniu potwierdzajacym wypowiedź; potwierdzajac zrozumienie np. polecenia;

(Z)ROZUMIENIE JAKO EFEKT JASNOŚCI, OCZYWISTOŚCI (20\%): sygnalizuje zrozumienie jakiegoś zagadnienia; przekazuje informację, że coś jest jasne; przekazuje informację, że coś nie wymaga głębszego wyjaśnienia; dany stan rzeczy jest logiczny/oczywisty/wynika z jakiegoś porządku rzeczy; przedstawianie ogólnie znanego faktu, przekaz podprogowy: „dlaczego $w$ ogóle pytasz, przecież to jasne”; kierujac 'to' wyrażenie do rozmówcy zakładamy, że wiedziat lub domyślat sie informacji jaka przekazujemy; wypowiadajac jakieś utarte pojęcia; gdy uważamy, że pytanie nie byto potrzebne; gdy coś jest oczywiste;

POKREŚLENIA (14\%): chcemy coś podkreślić $w$ wypowiedzi; (używamy gdy) chcemy podkreślić, że wiemy o jakimś zjawisku; (oznacza) dosadniejsze wyrażenie opinii; podkreślenie oczywistości danego faktu; podkreślając coś; „podbija” dobitność wypowiedzi; wskazanie;

UPEWNIANIE (4\%): upewnienie odbiory $w$ prawdziwości określonego twierdzenia; upewnienie odbiorcy $w$ właściwości określonego twierdzenia;

INNE: nie ma drugiego znaczenia; znaczeń jest nieskończenie wiele; dający jakąś prawdę.

Przy wyrażeniu „tak naprawdę” (w ramach użyć) mamy prawdę zdań i prawdę rzeczy - prawdę epistemiczną i prawdę ontologiczną. Rozróżnienie prawdziwości rzeczy a/i prawdziwości zdań ukazało się w przedstawionej charakterystyce użyć dla „tak naprawdę” przy wymiarach: INFORMACJE o (BUDOWIE I TREŚCI) WYPOWIEDZI oraz PRAWDZIWOŚCI 
WYPOWIEDZI. Potoczne pojmowanie prawdy zakłada, że sądy odzwierciedlają fakty, prawdziwe są takie, które odnoszą się do rzeczywistości. W skład najsilniejszych wymiarów dla „tak naprawdę” wchodzą takie użycia wyrażenia, które służą: ujawnieniu prawdy, wyprowadzeniu $\mathrm{z}$ błędu, podkreśleniu istoty sprawy, potwierdzeniu prawdziwości, wzmocnieniu wypowiedzi. Natomiast dla „na pewno” odpowiedzi wskazujące na użycie wyrażenia dotyczą wyrażania pewności, przekonania, powątpiewania, a dla „oczywiście” to wyrazy zgody, aprobaty, potwierdzenia i zrozumienia.

Zebrany materiał pozwolił uznać, że jednym $\mathrm{z}$ silnych celów przyświecających użyciu „tak naprawdę” jest dodanie wypowiedziom elementu perswazyjnego ${ }^{6}$, przekonaniowego, o zabarwieniu emocjonalnym. Cel (wy)powiedzenia prawdy, ujawniający się w przypadku „tak naprawdę”, przybliża takie użycia do aktów perlokucji, które J. Austin scharakteryzował jako „stwarzające coś, przez to, że się działa coś mówiąc7”. Efektem tego typu użyć/działań mową będzie: uświadomienie rozmówcy, wtajemniczenie go, wyprowadzenie z błędu. W przypadku „na pewno" i „oczywiście” jedne z kluczowych motywów używania to: potwierdzenia, upewnienia / uwiarygodnienia. Funkcjonują one często zamiennie $\mathrm{z}$ illokucyjnym aktem złożenia obietnicy. Nadto służą (wy)eliminowaniu wątpliwości. I. Adamska proponuje „oczywiście” 'of course' (i „rzeczywiście” , 'indeed') potraktować jako knowladge particles, zaś „na pewno" 'for sure' jako belief particles ${ }^{8}$. Wymiary dotyczące „sposobu użycia” wskazują na perlokucyjny charakter wyrażenia „tak naprawdę” i ukazują siłę illokucyjną „na pewno” i „oczywiście”. Wymiar POTWIERDZENIE został wyodrębniony przy każdym wyrażeniu, i w przypadku „na pewno/oczywiście” mamy do czynienia z „tak”, „zgoda”, zaś przy „tak naprawdę” nie tyle $\mathrm{z}$ „tak, naprawdę”, tylko z potwierdzeniem prawdziwości wypowiadanych słów. Generalnie, „tak naprawdę” to narzędzie służące ujawnianiu prawdy, przyznaniu się do czegoś, wyprowadzaniu $\mathrm{z}$ błędu, wskazywaniu istoty, ukazywaniu kontrastu, uściślaniu, podsumo(wy)waniu, wzmacnianiu wypowiedzi, zaś „na pewno”, „oczywiście" to instrumenty używane do zapewniania, potwierdzania, wyrażania zrozumienia bądź (sygnalizowania) wątpliwości.

Maria Ossowska wskazuje, że istnieją takie wypowiedzi, które „orzekając coś o przedmiocie $\mathrm{P}$ jednocześnie wyrażają jakieś doznania tego, kto się wypowiada”, które przeżywane są w stosunku do przedmiotu P, o którym wypowiedź orzeka9. Taki hybrydowy charakter posiadają (wypowiedzi zawierające) wyrażenia „tak naprawdę”, „na pewno” i „oczywiście” - mówią coś o stanie rzeczy X, (że jest prawdziwy, pewny, oczywisty) i jednocześnie ukazują, że jednostka przeżywa w odniesieniu do $\mathrm{X}$ doznania prawdziwości, pewności, oczywistości. Jednakże, taki sposób ujmowania

\footnotetext{
(Zob., więcej w: Niećko-Bukowska, 2009).

(Austin, 1962: 101; Austin, 1993) .

(Adamska, 2004: 19).

(Ossowska: 1994: 97).
} 


\section{Bożena Niećko-Bukowska: Charakterystyka znaczeń wyrażeń tak naprawdę, na pewno i oczywiście}

świata niesie ze sobą niebezpieczeństwa pozosta(wa)nia $\mathrm{w}$ błędzie na skutek brania przez jednostkę za prawdziwe (pewne, oczywiste) fałszu, bycia ofiarą celowego wprowadzania w błąd, sugerowania, że tylko 'ten dany stan rzeczy' jest naprawdę prawdziwy (oczywisty, pewny).

\section{Wnioski}

Jedną z funkcji jaką pełnią analizowane wyrażenia jest funkcja retoryczna emfaza obserwowalna w wymiarach WZMOCNIENIE WYPOWIEDZI czy PODKREŚLENIE. Czytelne elementy przekonaniowe, perswazyjne dostrzec można w wymiarze UWIARYGODNIENIE przy „na pewno” czy UPEWNIENIE przy „oczywiście”. Wypowiedzenie prawdy, pewności (o czymś) to nie tylko mówienie. Charakter sprawczy, performatywny wypowiedzi ujawnia się $\mathrm{w}$ takich czynnościach jak: uświadomienie, wtajemniczenie, wyprowadzenie $\mathrm{z}$ błędu, uwiarygodnienie, upewnienie, wyeliminowanie wątpliwości. Wyraźny jest także element emocjonalny, ekspresywny - jako wyraz gotowości uznania (czegoś), wyrażenie pewności, przekonania, emocjonalnego stosunku do wypowiadanych treści. Ewa Jędrzejko wskazała dwa rodzaje modalności: obligatoryjną (pozwala generować zdania oznajmujące, pytające, rozkazujące) i fakultatywną, w której można wskazać epistemiczną, deontyczną i aletyczną. Cechą charakterystyczną modalności epistemicznej jest jej związek z przekonaniami jednostki i odniesienie do stopnia pewności wyrażanych sądów. Modalność ta przedstawia coś jako pewne, wątpliwe bądź nieprawdopodobne ${ }^{10}$. W przypadku wyrażenia „na pewno” zebrany materiał wskazał na trzy stopnie funkcjonowania pewności: wysoki, średni i niski, przy czym wśród najsilniejszych wymiarów odnajdujemy obok wyrazów pewności, przekonania, uwiarygodnienia także powątpiewania. Modalność aletyczna ${ }^{11}$ dotyczy zdarzeń o charakterze obiektywnym, wobec których jednostka przyjmuje postawę konstatującą i za główne pojęcia tej modalności uchodzą „konieczność”, „możliwość”, „niemożliwość”.

Faktem jest, że najwięcej skojarzeń dla wyrażenia „tak naprawdę" budują odniesienia do tego, co „rzeczywiście”, „faktycznie”, co wpisuje się w klasyczne rozumienie prawdy jako zgodności myśli z rzeczywistością. R., Ziemińska12 zauważa, że klasyczna koncepcja prawdy jest ideą najprostszą, która dominuje w myśleniu potocznym, ale już w starożytności powstała wśród sofistów idea do niej alternatywna - relatywizm prawdy. W zarysowanych wymiarach dostrzec można także ekspresywne rozumienia. Mówiąc o ekspresywizmie, trzeba wspomnieć, że jest on w teorii prawdy odpowiednikiem emotywizmu w etyce. „Jest prawdą" będzie zatem wyrazem emocjonalnego stosunku do wyrażanych treści. Innymi słowy, powiedzieć „p jest prawdą”, to dać wyraz gotowości do uznania „p”13. Sprawczy charakter użycia, jak: uświadomienie rozmówcy,

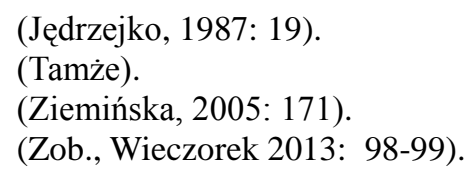


wtajemniczenie go, czy wyprowadzenie $z$ blędu należy odnieść do performatywnej teorii prawdy, która na gruncie deflacjonizmu otwarcie głosi, że prawda to performatyw (i należy wyeliminować pojęcie korespondencji) ${ }^{14}$. Tak jak w przypadku wyrażenia ,jest prawdą", wypowiadając „tak naprawdę”, „na pewno” czy „,oczywiście” dajemy wyraz wiary w daną wypowiedź, w prawo do działania w oparciu o przekonanie wyrażone w wypowiedzi. Nadto, predykat ,jest prawdziwe”, wyrażenie „tak naprawdę” czy „na pewno” są znakami aprobaty, zgody, dołączonymi do zdań oznajmujących, wyrazami wątpliwości $w$ pytaniach i braku przekonania w zdaniach warunkowych. Zwrot ,jest prawdą” można traktować także jako gest potwierdzenia (gesturing consent)15. L. Wittgenstein podkreślał, że chociaż słowa wyglądają tak samo, to jednak używane są do różnych rzeczy. Wypowiedzi z: „tak naprawdę”, „na pewno” czy "oczywiście” czasem uświadamiają, czasem potwierdzają, uwiarygodniają, wyprowadzają z błędu, bywa, że są wyrazem pewności, prawdziwości, powątpiewania - zależnie od kontekstu.

14 (Zob., Tamże: 97-98).

15 (Zob., Tamże: 98). 


\section{Bożena Niećko-Bukowska: Charakterystyka znaczeń wyrażeń tak}

naprawdę, na pewno i oczywiście

\section{Bibliografia}

Adamska, I. 2004. Oczywiście 'Of Course' and Rzeczywiście 'Indeed' - Two Different Types of Evidential Markers in Polish: A Relevance - Theoretical Account. W: Kardela, H., Sullivan W., Głaz, A. (eds.). Perspectives on Language, s. 9 -22. Lublin. Wyd. Uniwersytetu Marii Curie-Skłodowskiej.

Austin, J. L. 1962. How to do things with words. Oxford. At the Clarendon Press.

Austin, J. L. 1993. Mówienie i poznawanie: wykłady i rozprawy filozoficzne. Warszawa. Wyd. Naukowe PWN.

Jędrzejko, E. 1987. Semantyka i składnia polskich czasowników deontycznych. Wrocław-Warszawa-Kraków-Gdańsk. „Ossolineum”.

Niećko-Bukowska, B. 2009. Funkcjonowanie pojęcia prawdy na przykładzie potocznego użycia „tak naprawdę. W: Investigationes Linguisticae, vol. XVIII, s. 89-99.

Niećko-Bukowska, B. 2016. Oczywiście i po prostu - charakterystyka znaczeń wyrażeń. W: Komorowska E., Kondzioła-Pich, K., (red.). Komunikacja międzyludzka: leksyka, semantyka, pragmatyka. Vol. IV. Szczecin. Wyd. Volumina.pl.

Ossowska, M. 1994. Podstawy nauki o moralności. Wrocław, Warszawa, Kraków. Wydawnictwo Ossolineum.

Wawrzyniak, J., 2016. Etyka eutanazji. Studium filozoficzno-aksjolingwistyczne. Poznań. Wyd. Naukowe UAM.

Wieczorek, R. 2013. Współczesne minimalistyczne teorie prawdy. W: Ziemińska, R. (red.), 2013. Przewodnik po epistemologii. s. 87-113. Warszawa. Wyd. WAM.

Wittgenstein, L. 1997. Traktat logiczno-filozoficzny. Przeł. i wstępem opatrzył Bogusław Wolniewicz. Warszawa. Wydawnictwo Naukowe PWN.

Wittgenstein, L. 2000. Dociekania filozoficzne. Przeł., wstępem poprzedził i przypisami opatrzył Bogusław Wolniewicz. Warszawa. Wydawnictwo Naukowe PWN.

Ziemińska, R., 2005. Absolutyzm i pluralizm. W: Analiza i Egzystencja 1, s. $159-174$.

Zgółka, T. 1988. Język wśród wartości. Poznań. Wyd. Poznańskie. 


\section{Summary}

The analysis of the collected data allows to consider that one of the stronger aims which motivates the use of 'tak naprawdę' is adding an element of persuasion, of opinion, of emotion to the statement. The aim of expressing the truth, evident in the expression 'tak naprawdę, draws these types of uses of the expression close to perlocutionary acts. The aim of such acts is to make interlocutors realize, to acquaint or disabuse them. In the case of the expressions 'na pewno' and 'oczywiście' the key motivators of their use are: confirming, reassuring / making credible. Generally speaking, 'tak naprawdę' is a tool used to tell the truth, admit to something, disabuse, point to the crux of the matter, show contrast, specify things, summarize and emphasize them while 'na pewno/oczywiście' are instruments employed to reassure, confirm or express understanding or signal doubt. The (statements which use) expressions 'tak naprawdę', 'na pewno' and 'oczywiście' possess a hybrid nature - they state that $\mathrm{X}$ is real, certain, obvious and, at the same time, they show that an individual is aware of a sense of realness, certainty and obviousness towards that object $\mathrm{X}$. Of course, there always lurks the danger of being wrong and taking something that is false for something which is true/real, certain and obvious. It is also possible to consciously, purposefully attempt to mislead others - by suggesting that a given state of facts is real (obvious, certain) while, in reality, it is the opposite. Performative character of utterances can be observed in such actions as: making others realize, acquainting them, disabusing, making credible, confirming and reassuring, eliminating doubt. The emotive, expressive element is clear as well in such acts as signalling readiness to acknowledge something, expressing certainty, belief or an emotional attitude towards the words uttered. Most of the free associations for the expression 'tak naprawdę' are connected to that which is 'real', 'factual', which can be ascribed to the classical understanding of truth as the agreement between thought and reality. Similarly as it is the case of the expression 'it's true', by uttering 'tak naprawdę', 'na pewno' and 'oczywiście' we grant faith to the given statement, to the possibility of agency based on the belief expressed in that statement. Moreover, the predicate 'it's true' as well as the expressions 'tak naprawdę' and 'na pewno' are signs of approval, agreement which are added to indicative sentences, signs of doubt in interrogatives and signs of disbelief in conditionals. Expressions such as 'tak naprawdę', 'na pewno' and "oczywiście" happen to make people aware of facts or disabuse them, sometimes they confirm information and make it credible; they also can be signs of certainty, truthfulness, doubt - all depending on context. 
Bożena Niećko-Bukowska: Charakterystyka znaczeń wyrażeń tak naprawdę, na pewno i oczywiście

Appendix:

Characterizing the expressions within the SYNONYMS group:

For the expression 'tak naprawde' can be ascribed to the following dimensions: TRUTH: truth be told; honestly speaking; it's true that; truly; according to the truth; without lying; seriously / REALITY: in reality, really / PROPERTY, ATTRIBUTE: actually / GENERALISATION: on the whole; all in all; generally; admittedly it is / FACTS: in fact; according to facts / THE CRUX, ESSENCE OF THE MATTER: the thing itself; essentially; basically / OTHER: certainly; seriously, to all intents and purposes; however // For the expression 'na pewno': CERTAINTY: one hundred percent; certainly; sure; certainty; I am certain; undoubtedly; without a doubt; lit. as [sure, safe] as in the bank / FIRMNESS: irrevocably; I firmly believe that; it has to be that; it can't be any other way that; it must be that; definitely; unfailingly; inevitably; to be as it is / CLARITY, OBVIOUSNESS: clearly; it's exactly as; it looks exactly as; obviously! / PROBABILITY: most probably; probably; for certain / OTHER: truly; as a matter of fact; really; I believe that // For the expression „oczywiście”: CERTAINTY: absolutely; it's no saying that; without any doubt; without a doubt; unconditionally; quite so; one hundred percent; it comes with no doubt that; assuredly; it is certain that; certainly, certain; sure; of course it is that; of course it is not; it's true that; surely; truly / CLARITY: it's clear as day that; clearly; it's clear that; I can say with clarity that; evidently / FILLER WORDS: indeed; yes; true; quite so; in fact; essentially; completely; I agree; correct; oh sure; precisely / NATURALNESS: naturally / PREDICTABILITY: easy to predict; it could have been expected that; there was no other option than; as I've suspected; as usual; it is generally known that / UNDERSTANDING: lit. it gets to understand itself by itself; as we all know; it doesn't need much saying that; it's known that / OBVIOUSNESS: something obvious; obvious; it's obvious that; selbsverständlich / LACK OF TROUBLE: no problem; no worries; no trouble / OTHER: on the condition that; honestly speaking; synonym of the expression naprawdę; synonym of po prostu; straightforwardly.

Characterizing the expressions according to the 'WAYS OF USE':

For the expression 'tak naprawdę': Answers referring to the TRUENESS OF THE STATEMENT: RECTIFYING, ADMITTING TO HAVING SPOKEN UNTRUE: when we want to say the truth having lied before; when we joke or bend the truth, after which we rectify what we've just said; an attempt at rectifying something; pointing out that we lied before; showing something which we hid previously; when we want to 'expose' ourselves; employing a lie and quickly clarifying the situation; willingness to admit to something; admitting to something, after lying; admitting to something; the final and somewhat forced willingness to say 'the truth'; saying the truth / CORRECTING, DISABUSING: explaining the situation without lying; disabusing someone; discernish false 
information from correct information; correcting a false or incorrect answer; used to separate reality from may only seem to be the truth; making the interlocutor realize s/he's wrong; in contrary to what you think; searching for sense of a statement that is deeper than was is widely believed to be true one; but; however / CONFIRMING THE TRUTH: highlighting the truth of the information; when something is true; it means that we consider it true; confirming that what was said before is essential and true; confirming the information; an additional confirmation that one's telling the truth; confirming in case of doubt. // Answers referring to the INFORMATION ABOUT THE /FORM AND CONTENT/ OF A STATEMENT: SHOWING CONTRAST: highlighting the contrast between false information and its later verification; showing contrast between what you feel and what you do; expressing contrast between theory and practice; showing the opposite of a statement; when we want to indicate a contradiction or falsity / SUMMARISING, SPECIFYING, ENDING THE TOPIC OF THE CONVERSATION: As a summary of the information; summarising the topic of the conversation; specifying; making a statement more precise; withdrawing from the topic of the conversation / EXPRESSING AN ATTITUDE TOWARDS THE STATEMENT, STRENGHTENING THE STATEMENT: increasing the quality of a retort; used in order to add emphasis to a given sentence; strengthening the statement when someone does not want to believe us; used to highlight an expressed opinion; I am very convinced of what I'm saying; 'pay attention because what I'm going to say is important'; used to show the real state of our knowledge / HIGHLIGHTING, INDICATING THE CRUX, HEART OF THE ISSUE: highlighting the heart of the issue; highlighting what is most important; highlighting that the matter discussed is through-through; when one approaches the crux of the issue, what one would want to ask or say / OTHER: EXPRESSING AN OPINION, EXPRESSING EMOTION, MAINTAINING THE FLUENCY OF SPEECH: presenting a subjective opinion about a given topic; an introduction to giving an unofficial, semi-official statement; used to maintain the fluency of speech, hence it is difficult to provide its meaning; 'an empty expression', used to express emotions; it shows genuine desire or aversion to something.

For the expression 'na pewno': Three DEGREES OF CERTAINTY: (1) HIGH: EXPRESSING CERTAINTY: expressing certainty; highlights that one is certain of something; it shows certainty; one can be sure of it; when one is certain something is true; showing certainty in what one says; when we are certain of something; certainty that something exists; expressing one's complete certainty in a situation; when we are 100\% sure of a given situation; highlighting that one is certain of the information provided; being certain of something; appearing that something is true; confirmation / EXPRESSING CONVICTION: I am convinced that; expresses the beliefs of the person talking on a given subject; being convinced that something will happen or is; when we are convinced of something; when we subjectively believe something is true; 
Bożena Niećko-Bukowska: Charakterystyka znaczeń wyrażeń tak naprawdę, na pewno i oczywiście

something certainly happens/will happen; a subjective conviction about the trueness/realness (pol. prawdziwość); something took place; when we conjecture, have premises / CONFIRMATION: I confirm what I believe; I confirm something to which I am convinced (spoken with irony means the opposite); confirmation of certainty; a firm confirmation; when I want to confirm something / CREDIBILITY: we use it to provide our statements a high degree of certainty, credibility; strengthening of the words uttered, making them verifiable; emphasizing the message conveyed; a purposeful highlighting of the truthfulness of the statement; confirming that something is true; used to substantiate one's certainty / (2) MEDIUM: ASSUMPTION: expressing an assumption referring to the future; expressing one's opinions, assumptions; when we predict something; something will be done; expression of assumption / (3) LOW: SIGNALLING DOUBT: depending on the intonation it may express doubt and lack of belief in what the interlocutor says; in questions used to signal the interlocutor that s/he may not be right; we use it when we hear something which to us seems improbable; ironical in situations of disbelief; at the beginning of an interrogative question in case of doubt; expresses irony; used ironically to highlight absurdity; when we would never want to do something / MAKING CERTAIN: when we want to make sure of something, we ask; the need to make certain that the information is correct; making sure / OTHER: EMOTIONS, EFFECTS ON OTHERS: expresses irritation; a promise; reassuring others/comforting.

For the expression 'oczywiście': A SIGN OF AGREEMENT/ (DIS)APPROVAL: expressing approval; showing approval; expressing absolute certainty regarding something; expressing agreement; agreeing with someone; it expresses that we agree with something/someone; I agree; a positive reaction to a question; a praise; a sign of readiness to do something; sarcastic; no; disapproval / CONFIRMATIONS: I confirm; confirmation; a confirmation of the statement's correctness; this expression can confirm every sentence; used in a meaning confirming a statement; confirming the understanding of an order, for example / UNDERSTANDING AND GETTING TO UNDERSTAND AS AN EFFECT OF CLARITY, OBVIOUSNESS: signals the understanding of an issue; conveys the information that something is clear; conveys the information that something does not require further explanation; the given state of facts is logical/obvious/results from an order of things; stating a wellknown fact, subliminal message; 'why are you even asking me this, it's clear as day'; by directing 'this' message to the interlocutor we assume that s/he knew about or could guess the information we were trying to express; saying some commonplace notions; when we think that the question was not needed; when something is obvious / HIGHLIGHTING: we want to highlighting something in the utterance; (used when) we want to highlighting that we know of a phenomenon; (means) a emphasized way of expressing an opinion; highlighting the obviousness of a given fact; highlighting something; 'buffs' the firmness of the 
statement; underlining / REASSUREMENT: reassuring the receiver of the message of its truthfulness; reassuring the receiver of the message of its properties / OTHER: has no second meaning; there is an infinite number of meanings; conveying some truth. 